\title{
Epidemiology of Zoonoses Geared by Domestication with Reference to COVID-19 during Anthropocene; India
}

\author{
Siba Prasad Mishra ${ }^{{ }^{*}}$ and Saswat Mishra ${ }^{2}$ \\ ${ }^{1}$ Department of Civil Engineering, Centurion University of Technology and Management, \\ Bhubaneswar, India. \\ ${ }^{2}$ National Institute of Construction Management and Research, Bahadurgarh, Delhi NCR, India.
}

\begin{abstract}
Authors' contributions
This work was carried out in collaboration between both authors. Author SPM designed the study, performed the statistical analysis, wrote the protocol and wrote the first draft of the manuscript. Author

SM managed the literature searches. Both authors read and approved the final manuscript.
\end{abstract}

Article Information

DOI: 10.9734/ARRB/2020/v35i930271

Editor(s):

(1) Dr. Saleha Sadeeqa, Lahore College for Women University (LCWU), Pakistan.

(2) Dr. Paola Angelini, University of Perugia, Italy.

(3) Dr. Ahmed Medhat Mohamed Al-Naggar, Cairo University, Egypt.

Reviewers:

(1) Kalpani Omantha Bandaranayaka, Management and Science Institute (MSI), Sri Lanka.

(2) Ibrahim H. A. Abd El-Rahim, Umm Al-Qura University, Saudi Arabia.

(3) Srikanth Naramala, Adventist Medical Center, USA.

Complete Peer review History: http://www.sdiarticle4.com/review-history/60644

Review Article

Received 13 August 2020

Accepted 31 August 2020

Published 31 August 2020

\begin{abstract}
COV-19, HIVIAIDS, Flu H1N1 and many other zoonotic diseases are emergent during Anthropocene epoch due to climatic anomalies. Bacteria's, viruses, pathogens are associated with human cause zoonoses mainly resulting from domestication. Minimum $61 \%$ of human pathogens are zoonotic comprising $75 \%$ of all emerging apocalyptic pathogens in 21 st century. The scope of present study is investigating the domestication in time scale and finding the causes and consequences the virulent invasion of the present $21^{\text {st }}$ century zoonotic diseases due to the climatic, biologic, socio-economic causes and the governing laws during the Anthropocene. The Holocene hominids were strong enough to adapt the harsh, frigid climate to sustain life during extreme conditions. Later the food habits, sedentary life and the changing agro-climate made then incapable to sustain with the bacterial, viral and microbial attacks for lack of immunity and adaptability by invoking domestication. The National Health Profile, India; has reported fall in rate of
\end{abstract}


communicable diseases that has out broken from $61 \%$ to $33 \%$ from 1990 to 2016 resulting from health education, care and vaccines but the pandemicCOVID-19 has challenged the scenario. Demand of one health practices and stringent laws is essential to overcome the risk. Present pandemic COVID-19 has forced the globe away for sustenance of life and livelihood for want of vaccine, it is essential to practice five ' $T$ ' (Test, Trace, treat, train and trade) to restore the normal life.

Keywords: COVID-19; domestication; virus; bacteria; Zoonoses; Anthropocene; one health.

\title{
ABBREVIATIONS
}

\author{
ZD : Zoonotic diseases; \\ MOH\&FW, GOI : Ministry of Health and Family Welfare< Govt. Of India; \\ E : Endemic; \\ $P \quad:$ Pandemic; \\ H1N1 Flu : Swine flu; \\ MP : Madhya Pradesh \\ UP : Uttar Pradesh \\ Ind :India; \\ M-rastra : Maharashtra; \\ K-Taka : Karnataka; \\ R-than :Rajasthan; \\ ZD : Zoonotic diseases \\ GTS : Geological time scale; \\ CBHI : Central Bureau of Health Intelligence; \\ DALY's : : Disability adjusted life years; \\ KFD : Kyasanur Forest Disease \\ RVF : Rift valley fever \\ AES : Acute Encephalitis Syndrome \\ NHP : National Health Profile; \\ Intelligence LIA : Little Ice age; \\ AES : : Acute Encephalitis Syndrome; \\ ARDS : : Acute Respiratory disorder syndrome; \\ SARS : Severe acute respiratory syndrome; \\ AP : Andhra Pradesh; \\ TN : Tamil Nadu; \\ WB :West Bengal; \\ HCU : Health care Units; \\ ZDR : Zoonotic Disease Reservoir; \\ ky BP : Thousand years before present
}

\section{INTRODUCTION}

The human evolution from Pleistocene is concomitant with petting the plants and animals for food, security and satisfying bare necessities like agriculture, transport, cladding, fashion, comfort and medicine from Paleolithic age. The post Paleolithic age is Old Stone Age; (4010Kyear BP), followed by Mesolithic (Middle Stone Age; 10.0- 4.0kyear BP) to Neolithic (New Stone Age; 5.0 to $1.8 \mathrm{ky} \mathrm{BP}$ ) and the present is the Chalcolithic Age ( $\approx 1.8 \mathrm{ky}$ to $1.0 \mathrm{ky} \mathrm{BP})$ are of Holocene epoch. Globally, origin of domestication of flora, fauna, avifauna, and aqua-fauna are dates back to $\approx 14000$ years BP in last glacial lce age. Later the period became warm, humid and promising SW monsoon in India had favoured growth of forest and grazing ground with intermittent ice ages. The 11700 years Holocene epoch has been left to Anthropocene Epoch from 1945 (Fig. 1) (https://humanoriginssi edu/research lagehumans-evolutionary-perspectives anthropoceneandhttp://www.geologyin.com/2014 /12/geologic-time-scale-major-eons-eras.html.

Proper health care should reinforce public health, warrant quality and provide equitable human centric sustainable life expectancy. But the rising trend of life expectancy is at threat for last 2-3 years. The year 2018; India was under threat due to zoonotic diseases (ZD) like Influenza H1N1 
(14971 hosts), rabies (110 cases), Kala-azar (4380 cases) chikungunya (57813 cases), Japanese Encephalitis (JE) (1674 cases), and Dengue (192 cases). Plague had caused death toll of 12 millions, H1N1 10-21 mn and rabies 20k people in past when the India's population was resurfaced during early 19th\&20th century (Swain S K et al. [1] from CBHI; MOH\&FW GOI). Diseases like plague, Nipah, KFD (Kyasanur Forest Disease), Malaria etc. have become common virulent diseases in India which has forced India to go for observing 21st, July, 2020 as Zoonosis' Day globally (CBHI, DGHS 2019). The domestication of animhas invited many virus to home and made the human health vulnerable. The figure urges for not leaving the Zoonoses in the hands of physicians and zoologists but common people should be aware of the artifact (Fig. 2).

About $61 \%$ of human microbial pathogens with $13 \%$ are reemerging. The ZD's covers about $75 \%$ of all emerging apocalyptic pathogens of 21st century. Covid-19, (the present reemerging virus), HIVIAIDS and many other virulent ZD's are prioritized with high scores of vulnerability for human health during present Anthropocene Dubal et al. [2] and CBHI 2018 [3].

The domestication is only $12000 Y$ old in India. The viral and vector borne diseases are wide spreading due to the zoonotic and domesticated fauna. The zoonotic ailments were virulent from Bubonic plague, Flue H1N1, Cholera, Small pox, TB (Tuberculosis), malaria and AIDS in India during $19^{\text {th }}$ and $20^{\text {th }}$ century. But the viral diseases like Japanese Encephalitis (JE), Ebola, MERS, and SARS have challenged human health and above all the COVID-19 throughout the globe including the country India in early $21^{\text {st }}$ century (Swain et al. [1]). However, the ZD's like Covid-19 has surpassed all the limits covering all over the globe affecting recorded or unrecorded $18+9 \mathrm{mn}$ cases/ 693+k deaths throughout the world and $18+\mathrm{mn}$ cases $/ 38+\mathrm{k}$ deaths from India till $3^{\text {rd }}$ Aug 2020 (World o meter of COVID-19 statistics [64]).

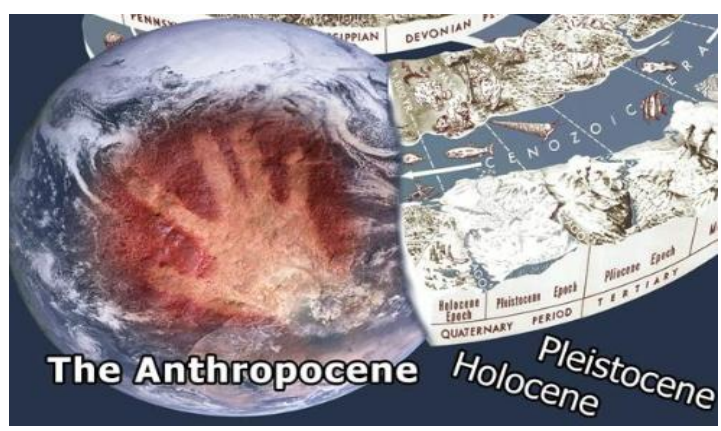

Fig. 1. The Anthropocene Epoch; the age of Man; Geological time scale from Pleistocene

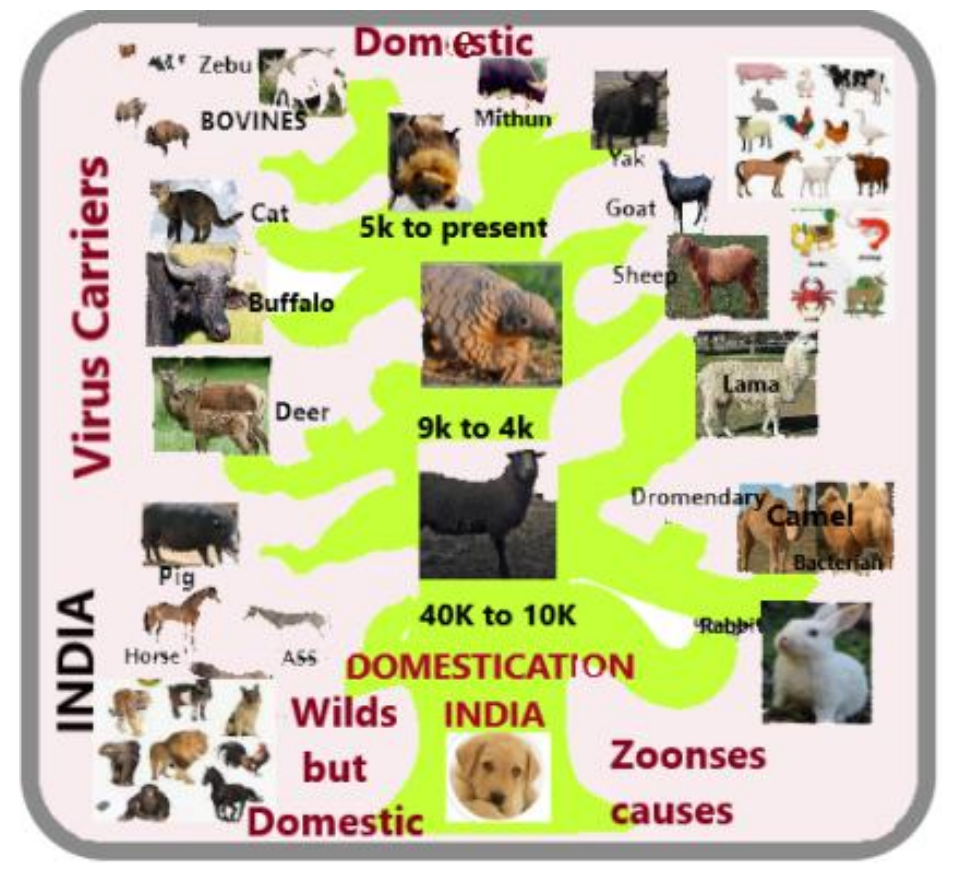

Fig. 2. The domestication of different animals and Zoonosis tree in Indian species 


\subsection{Review of Literature}

Domestication of wilds is one of the supreme attainments in Indian cultural history in its evolution processes and sustenance for food, cloth, transportation, warfare, fascination, (Nath B, [4], Thomas P. K. [5]). The domestication processes was initiated by the human species through hunting, farming and transportation, Darwin C R, 1868 [6], Clutton-Brock J, 1987 [7], Francis RC 2015 [8], Alves et al. [9], Teletchea F [10]. Human efforts for domesticating the wilds to augment food necessity on population rise, food flexibility, shift from hostility to captivity, and captive breeding. The social hierarchy modification had shaped animals and human under panic and distress. The viruses/vectors are the causes for proliferation of the zoonoses. They are from pigs, bats, dogs, cats, mosquitoes and many other insects or microbes. They are the disease makers which is mainly due to poor human-animal-environment interactions (https:// www.who.int/zoonoses/en/, Ahamad T., et al [11]. In past; plague, flu, cholera and rabies had scraped and levelled the human population in India, Yasobant et al. [11], Sanjay Ku., et al [1].Further the $21^{\text {st }}$ century viruses like Ebola, MERS, and SARS etc. have endangered the very human existence on earth as a part of $6^{\text {th }}$ extinction, Mishra S. P. [12].

India is presently the $3^{\text {rd }}$ hot-spot country of the globe suffering from COVID-19 due to emergence of virulent zoonotic disease (ZD. About58\% out of 1407 human pathogens (bacterial and Rickettsia, fungi, viruses helminths, and protozoa comprising of 538,317 , 208, 287, and 57 numbers respectively) are Zoonotic and 22 numbers were deadly causing 2.2 million mortalities annually, Sehegal S., [13], Dhiman et al. [14], Chinchwadkar P., et al. [15] as per, RCZI report, Swain S K., et al. [1]. Anthropogenic causes for spread of ZD's through domestic animals are due to contact, minimum social distancing, food, unhygienic dwelling, ignorance, poverty, occupation and poor lifestyle. The ZD's are influenza HN series, Japanese encephalitis, Monkey pox, Nipah, plague, Marburg, leishmaniosis, rabies, anthrax, leptospirosis, HIV, Kyasanur Forest Disease (KFD), Ebola, SARS, MERS and Corona Virus SARS -2.Bhatia B. B. [16], Traub et al. [17], Andresiuk V et al. [18], Deplazes P, et al. [18], Singh B. B. et al. [21], Dhiman R C et al. [14], Ahamad H. I. et al. [11]. During early $20^{\text {th }}$ century, India had lost 20 to $40 \mathrm{mn}$ people suffering from H1N1 Spanish flu during 1918 globally. Arbovirus diseases in India like JE, Dengue \& Chikungunya, H2N2 (Asian flu), H3N2 (Hong Kong flue) and recurrence of $\mathrm{H} 1 \mathrm{~N} 1$ caused millions of deaths in India, (Paul Canway, PhD thesis, Michigan University, Open. Michigan).

\subsection{The Past/present Epoch}

According to the Geological time scale (GTS), the geologist and geo-chronologists; the human species has become dominant over geo-biohydro sphere including the atmosphere since the Holocene epoch ( $\approx 12000 y r s$ BP). Cruzen and Dobemier-2000 claimed that the earth was superseded by a new Epoch from the clutches of previous short-lived Holocene to the Anthropocene from 1945; (Cruzen et. al. [22], Zalasiewicz J., et al. [23], Mishra S .P. et al. [24]). After numerous dialogues of the Anthropocene working groups (AWG); in 2016 the novice epoch (the Anthropocene) was recommended as part to the Int. Chronostratigraphic Chart. Based on the proceedings the Geologists are after official approval from ICS (International Commission on Stratigraphy) but opposed by many paleologists coordinating the human-nature interactions due to cultural changes and environmental impact, Lewis et al. [25], Leclain T J. [26], and Ellis et al. [27].

\subsection{The Origin of Domestication}

The nomad and wandering aboriginals were being mutated to modern man. They gradually dominated the earth on conversion from hunter gatherer to agriculturists. The dogs are the first pet to accompany the hunters. The sheep and cattle's were next to be domesticated by the agrarians. Later large numbers of live stocks were domesticated. The practice of agriculture based communal livelihood and sedentary life lured them to tame cats, cows, horses and even big elephants to satisfy their settlement for food, transportation, hunting and war. They could use polished and grinded weapons, housing materials, gadgets, shaping pottery, make paintings, melting ores to metals for their sustenance. Modern people lived in caves or huts. When they were hunters and food gatherers, their average life span was 20 to 25 years but with agriculture their life expectancy elevated to 40-50years (https://vimeo. com/272950415).

The recorded drought and famine, meteorological, geological extreme events, the 
epidemics and pandemics, had surfaced human population in India in past. After little Ice age, India faced the mediaeval warm period between the years 900AD to 1300AD, Sinha et al. [66]. During this period there were occurrences of intermittent failure of crops (Droughts and famines), cyclones and many climatic factors had worst impact on the people of Indian subcontinent $[19,20]$. The catastrophe were added with a numbers of zoonotic diseases like Bubonic plague, Cholera, TB, Flu (H1N1), smallpox and many other ZD's. However invention of vaccine could control them but some VD's are emerging or reemerging in the present $21^{\text {st }}$ century and are apocalyptic.

\subsection{Domestication of Animals in India}

The importance of domestication of animals in India became protuberant dating back to Neolithic culture i.e. 9000 yrs to 4000 yrs BP in Indian subcontinent but during Mesolithic period the evolution was in peak (mythology). The green and cultivable areas were occupied then by the Aryans in NW-region (Indus valley) Northern region (Kashmir valley), SE region (Upper Gangetic and Yamuna river valleys in UP), Bellan valley (Mirzapur, Rewa areas), Mid east region (Upper Bihar), NE region (Assam), Central eastern region (Chhotnagpur plateau to Odisha and WB) and southern region (Peninsular India) where the imprints are found by archeological excavations from Adamgarh (MP); Mehrgarh (Pakistan) and Sambhar lake (Rajasthan) due to ample Westerly and SW-ly rainfall, The findings were dating back to $7 \mathrm{k}$ to $6 \mathrm{k}$ yrs. BP which had resulted from transformation of human life style from nomadism to sedentary agricultural living (Zeder M. A., et al. [28] and [29], Larson G. et al. [30], Scherf and Pilling, [31]; Leroy et al. [32], Teletchea F et al. [33], and [34] Mishra SP [35]).

The trend in domestication of Bovines, horses, camels, mules, and donkeys were due to mechanization. The rise in poultry population is increased drastically as it has become a part to our diet. India has the largest numbers of dairy cow population from foreign IAS breeds in the world. Washington post in its daily edition July $16^{\text {th }} 2018$ reported about $5.2 \mathrm{mn}$ of stray cows in India without being productive. The population trend of domestication is in Fig. 4.

\subsection{Mythology and History of Domestication}

According to mythology and history, the domestication evolution process in India was dateable to Manu, Vedic era and the ethic Ramayana and Mahabharata during Aryan civilization in India (9000- 4000 yrs. BP). They are proved from the archeological excavations, at sites Hoshangabad and Adamgarh (Peninsular India), Bagor and Bhilwara in western India. The Legends and mythology with proxies and exhibits of dogs, sheep, water Buffalo, goats and cattle's were domesticated in early India (Mishra S.P. 2020 [35]), Joshi et al. [36] and Alur KR [37].

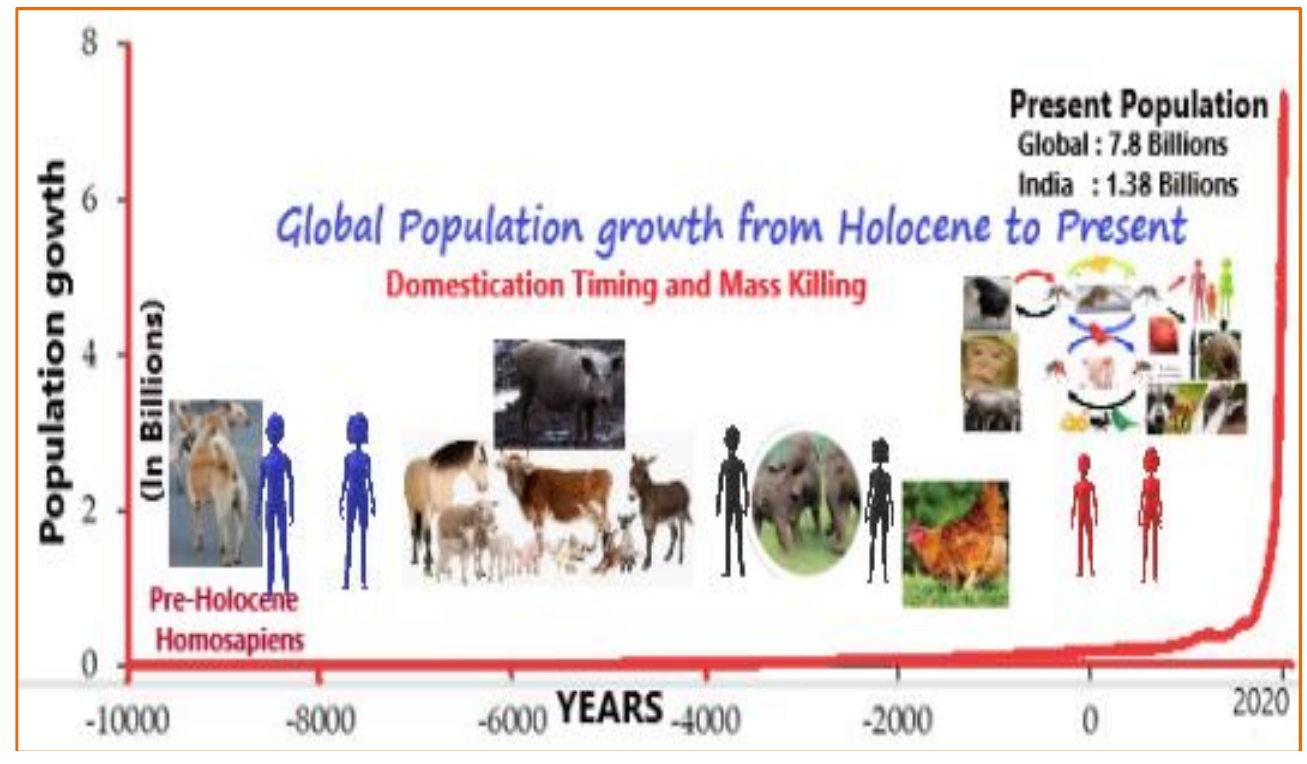

Fig. 3. The statistics of Homosapiens growth, period wise domestication 


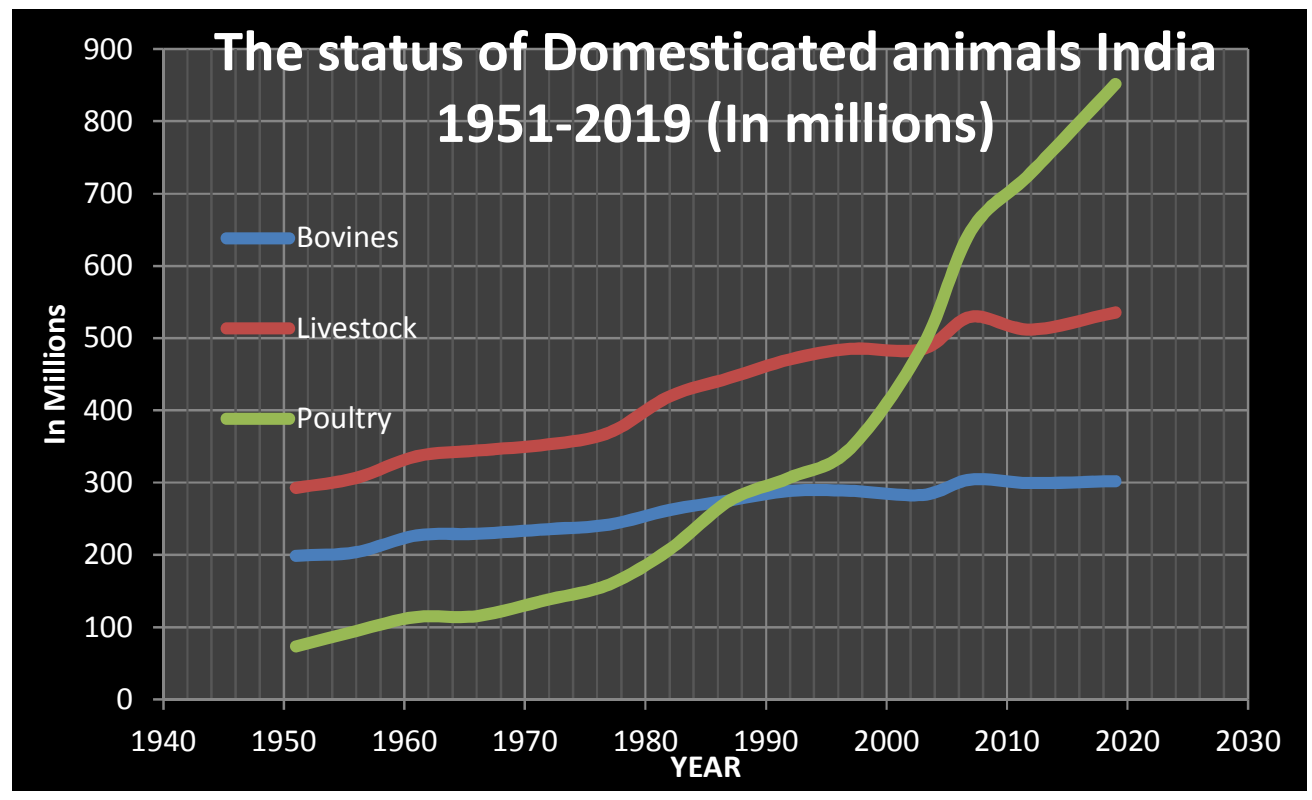

Fig. 4. The trend of bovines, live stocks and poultry population during the present anthropocene

Some wild animals fascinated for domestication with least societal use to the modern man like monkeys, bears, Pigeons, foxes, parrots, eagle, and even the worst predators the leopards, tigers and lions. The time line for domestication and transformation of wild animals to native occurred due to their habit, behavior, feed reproduction, safety and appearance is given in Table 1.

\subsection{The impact of Domestication}

The Zooneses cropped into human health with association of domestic animals where their population was high in the environment. The changes in diet, population explosion, breeding the animals, temperature, life style, transformations and hierarchy of the animals in the taming process catered the zoonoses. As a result the human health was under threat and had caused large deaths for want of awareness, vaccination, medicine and treatment procedures.

\subsection{Zoonoses}

Zoonoses (Rudolf Virchow; 1880) is the mutually shared diseases among human-animal and nature whereas WHO (1959) reported Zoonoses is the transmission of diseases and infections from animal to human and vice versa under natural environment. During mid and post Holocene the dominance of these zoonotic diseases were surfacing the human species but was not given importance and were considered as an act of supper power. The globe has encountered the cataclysms of the ZD like Smallpox, Plague, Anthrax, and Cholera in time gaps. But emergence and recurrence of the diseases is stressed upon for its catastrophe for last 20 years. The pets and some domestic animals have emerged infections, Day M.J. et al. [40], Carol Rubin, [41], Rist et al. [42].

\subsection{Zoonoses in History}

Zoonoses are contemporary of domestication. The bubonic plague was reported in the Old Testament, (Samuel), the Black Death was apocalyptic during $14^{\text {th }}$ in Eurasia, Asia, and Africa Rabies was reported among hunting dogs of Mesopotamia civilization 5000 to 2000Yrs BP and later in China, Egypt, Greek, and Rome. Alexander the Great died at Babylon by West Nile encephalitis virus in $323 \mathrm{BC}$.

India covers $2.4 \%$ of the global mainland but obliging $\approx 7-8 \%$ of the species kingdom and a divergent biodiversity hotspot. India is one of the anchoring zone lying in the pathway of faunal exodus between the Asia (East) Australasia, central Asia- Afro Eurasia flyways amid the eight avian paths of the globe that encourages propagation of Zoonoses Mishra S. $P$., et al. [43]. The etiology agents of ZD'S are in Table 2. 
Table 1. The different ages of domestication and human transformations and weather

\begin{tabular}{|c|c|c|c|c|c|}
\hline Age in Quaternary & Th. ky BP & $\begin{array}{l}\text { Domestication of } \\
\text { animal }\end{array}$ & kyrs BP (domesticated) & Whyl Origin country/r & Ancestors \\
\hline Paleolithic (upper) & $40-10$ & Dog, sheep & $20-10.5 \mathrm{k}$ & $\begin{array}{l}\text { China,East Africa/ pet / } \\
\text { food/milk }\end{array}$ & Jackal, grey Wolf \\
\hline $\begin{array}{l}\text { Paleolithic (Middle) } \\
\text { Pre-Holocene }\end{array}$ & $\begin{array}{l}9.0-4.0 \\
\text { (draught } \\
\text { animals; } \\
6 \mathrm{k} \mathrm{BP}) \text { ) }\end{array}$ & $\begin{array}{l}\text { Pig } \\
\text { Goat } \\
\text { Cattle } \\
\text { Zebu (cow) } \\
\text { Cat } \\
\text { Chicken } \\
\text { Donkey, Honey bee } \\
\text { Buffalo } \\
\text { Camel, Horse } \\
\text { Duck; silk moth } \\
\text { Food grains }\end{array}$ & $\begin{array}{l}11 \mathrm{k}-10 \mathrm{k} \\
11 \mathrm{k}-10 \mathrm{k} \\
10 \mathrm{k}-9.5 \mathrm{k} \\
10 \mathrm{~K} \\
10 \mathrm{k}-9.5 \mathrm{k} \\
7 \mathrm{k}-6.5 \mathrm{k} \\
8 \mathrm{k} \text { to } 6 \mathrm{k} \\
6 \mathrm{k} \\
6.5-5.0 \mathrm{k} \\
6 \mathrm{k} \\
8 \mathrm{k}-\text { extant } \\
8 \mathrm{k}-\text {-extant }\end{array}$ & $\begin{array}{l}\text { China (Food, milk/ cloth) } \\
\text { Iran (Food, milk/ cloth) } \\
\text { India, Mid. East, Africa } \\
\text { (Food, milk/ cloth) } \\
\text { Africa (pet, paste, cloth) } \\
\text { SE Asia Woods (Food) } \\
\text { Egypt (Milk, meat, honey) } \\
\text { India, China(Milk/meat) } \\
\text { Eurasia, Iran (Transport) } \\
\text { China (Food) } \\
\text { Africa, Asia, Eurasia } \\
\text { Africa, Asia, Eurasia }\end{array}$ & $\begin{array}{l}\text { Wild Boar } \\
\text { Wild Goat } \\
\text { Aurochs } \\
\text { Aurochs,India } \\
\text { Wild cat } \\
\text { fowl (Gallus) } \\
\text { Onager or Khur } \\
\text { Wild buffalo } \\
\text { Own Wild type } \\
\text { Mallard } \\
\text { From wild variety } \\
\text { Their wild seeds }\end{array}$ \\
\hline $\begin{array}{l}\text { Paleolithic (Lower) } \\
\text { Mid Holocene }\end{array}$ & $5.0-2.8$ & $\begin{array}{l}\text { Elephant, camel } \\
\text { Goose, poultry } \\
\text { Honey bee, Peacock, } \\
\text { Parrot, pigeon }\end{array}$ & $\begin{array}{l}4.5-4.0 \mathrm{k} \\
5.0 \mathrm{k} \\
4.5 \mathrm{k} \\
\approx 5.0 \\
\approx 5.0 \mathrm{k} \\
\approx 5.0 \mathrm{k}\end{array}$ & $\begin{array}{l}\text { Africa, India (Transport) } \\
\text { Germany (Food and pet) } \\
\text { Africa, USA (Honey) } \\
\text { India (Food, feathers) } \\
\text { India, Africa, Asia (Pet) } \\
\text { India, Africa, Asia (Pet) }\end{array}$ & $\begin{array}{l}\text { Own Wild type } \\
\text { Anatidae } \\
\text { Wild Bee } \\
\text { Wild Peafowl } \\
\text { Wild Parrot } \\
\text { From their wild }\end{array}$ \\
\hline Chalcolithic & $2.8-1.0$ & $\begin{array}{l}\text { Turkey } \\
\text { Rabbit }\end{array}$ & $\begin{array}{l}2 \mathrm{k} \\
2.8 \mathrm{k}\end{array}$ & $\begin{array}{l}\text { Mexico (Food) } \\
\text { Europe (Food \& pet) }\end{array}$ & $\begin{array}{l}\text { Wild Turkey } \\
\text { lberian rabbit }\end{array}$ \\
\hline LCA; Post Holocene & 1.0 to75 & $\begin{array}{l}\text { Ostrich/Emu } \\
\text { Sugar, }\end{array}$ & $\begin{array}{l}1866 \\
19^{\text {th }} \text { cent }\end{array}$ & $\begin{array}{l}\text { South Africa (Food) } \\
\text { Asia (Food) }\end{array}$ & $\begin{array}{l}\text { Own wild type } \\
\text { Wild plant }\end{array}$ \\
\hline Anthropogenic & 1945- present & $\begin{array}{l}\text { Red fox } \\
\text { Hedgehog }\end{array}$ & $\begin{array}{l}1950 \\
1980 \\
\end{array}$ & $\begin{array}{l}\text { USSR (Fancy pet, Tame) } \\
\text { Africa (Pets) }\end{array}$ & $\begin{array}{l}\text { Wild red fox } \\
\text { Wild variety }\end{array}$ \\
\hline
\end{tabular}

Animal. Gupta A.K., 2004 [38], Zeder MA. 2008 [28], Teletchea Fabrice, 2019 [34]; McHugo, G. P. 2019 [39] 


\section{Table 2. Zoonotic diseases, and the sources and their trend during Anthropocene epoch}

\begin{tabular}{llll}
\hline$\#$ & Etiology agents & The Zoonotic diseases & Rise or reduction at present \\
\hline 1 & Bacterial & Anthrax, plague, leptospirosis, salmon ellosis, lyme disease, brucellosis, & Reducing( antibiotic availability) \\
2 & Viral & rabies, arbovirus Flu (SARS-CoV-2, MERS), KFD, yellow fever, influenza, CCHF & Dominantly rising; antiviral yet to come \\
3 & Rickettsia & Murine or tick or scrub typhus, Q-fever & Least Prevalent (Vit D available) \\
4 & Protozoal & Toxoplasmosis, trypanosomiasis, leishmaniasis & Least Prevalent \\
5 & Helminthic & Echinococcosis, taeniasis, Schisto-somiasis, dracunculiasis & Reducing (Health education) \\
6 & Fungal & Deep mycosis - histoplasmosis, crypto-coccosis, superficial dermatophytes. & Reducing; Health education \\
7 & Ecto-parasitic & scabies, myiasis & Source: https://ncdc.gov.in/WriteReadData/l892s/File618.pdf
\end{tabular}




\subsection{Factors Responsible for Zoonoses}

The various factors responsible for emerging/ reemerging zoonoses are change in etiology of human species and cause ZD's like Plague, RVF, KFD and many others. Frequent traveling or migration (temporary/ permanent) or natural insanitary habits and social closeness may cause COVID-19, Yellow fever, MERS, giardiasis, and amoebiasis etc. Consuming spoiled meat, food, handling animal wastes, crowding of animal, cause $\mathrm{s}$ anthrax, giardiasis, food poisoning, TB, salmonellas is. The Hantan virus, E. coli, dermatophytosis, bird flu, swine flu and many other ZD's also are manifested.

\subsection{Zoonoses and $6^{\text {th }}$ Mass Extinction}

The natural and anthropogenic burdens have made $\approx 32,000$ species (out of 120,372 species) threatened and vulnerable to extinction which is $27 \%$ of the total samples measured. These species are composed of $26 \%$ mammals, $41 \%$ amphibians, $34 \%$ conifers, $14 \%$ avi-fauna, $30 \%$ sharks and Rays, $33 \%$ coral reefs and $28 \%$ selected crustaceans from their classes (IUCN Red list, [44]). The aboriginal species of human are observed under vulnerable under extinction are some tribes of Odisha (Dongaria Kondhs), MP (Baigia tribes), Andamanese (Bo, Sentinelese, Jarawa and Onge) of AASI (Ancient Ancestral South Indians of Australian origin). Moreover the disease COVID-19 has geared Indians the reverse migration which may inculcate increase in vulnerability of indigenous aboriginal and ethnic people of India. The aboriginal a small pocket of AASI of the great Andamanese comprising of Jarawa's (520 people), Onge (124 people), Shompen (200 people) and the Sentinelese (60persons) are left. Many tribes in India are in the extinction process due to modernization, https://www.pmfias. com/iucn-red-list-india-red-data-list-red-book/.

\subsection{Health Maintained States India}

The people's health of a state is judged from its neonatal and geriatrics fitness. The geriatric group of people of India lacks their health as neglected economically or socially and is the major victims (Fig. 5). Disability-adjusted life years (DALYs) has reported there is drop in overall disease burden from $61 \%$ to $33 \%$ between 1990 to 2016. But chronic noncommunicable (NCD) diseases (CVD), diabetes, COPD, cancers, mental health disorders have surged from have surged from 1990-2016.

The state Kerala followed by HP and TN are the best performer in HCU of their people. The DALY report of NHP $-2019(\mathrm{CBHI})$ has mentioned that the epidemiological transmission in India varies for non-communicable diseases (48-75\%), human communicable and associated diseases $(14-43 \%)$ and self-injuries $(9-14 \%)$. The prevalence rates of various infectious diseases fluctuate from year to year (2017 has less report than the year 2018) CBHI-2018 [3]. The status of appearance of various zoonotic diseases in India is in Table 3.

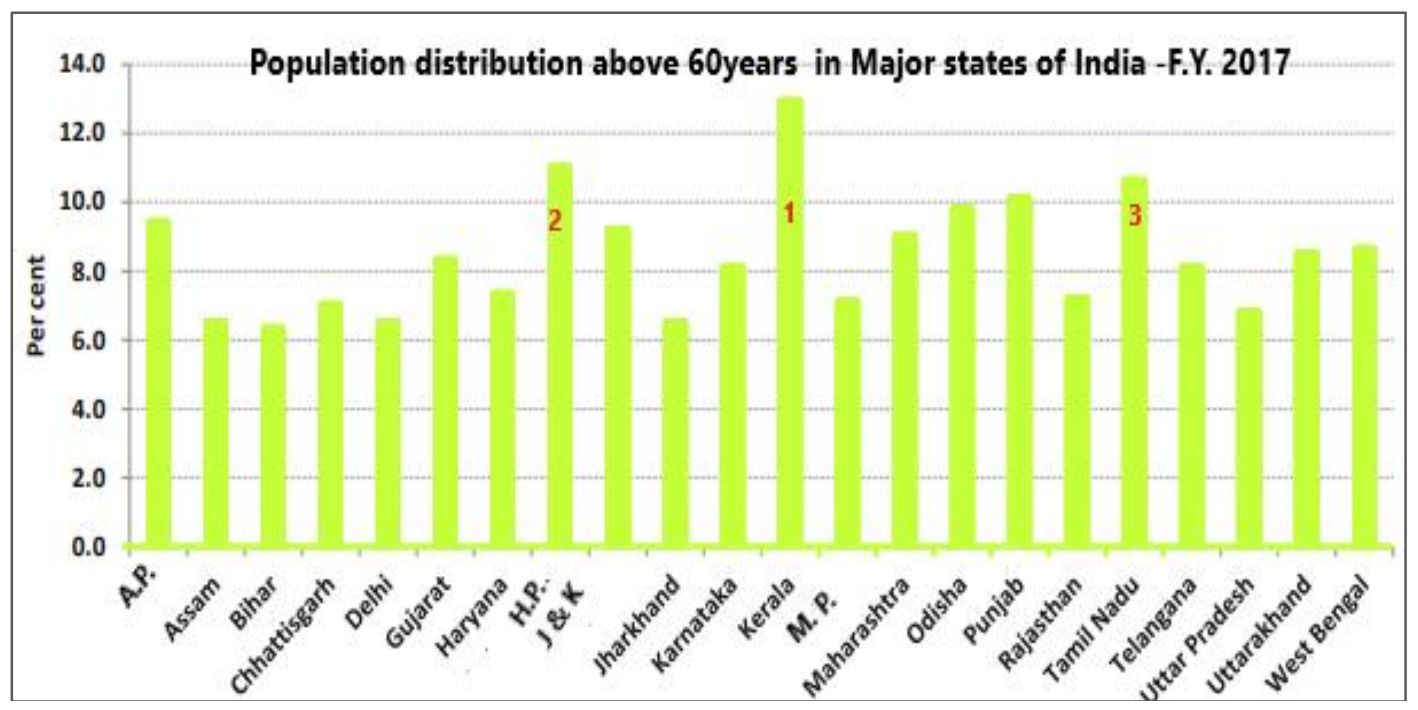

Fig. 5. The state wise population distribution in (\%) of geriatric group India (FY 2017) 
Table 3. The major Zoonoses, the numbers of cases causing deaths in India in last $\mathbf{5}$ years

\begin{tabular}{|c|c|c|c|c|c|c|c|c|}
\hline \# & The ZD's & 2013 & 2014 & 2015 & 2016 & 2017 & 2018 (P) & ZD Reservoir (ZDR) \\
\hline & & Cases/deaths & cases/ deaths & cases/death & cases/death & cases/death & cases/death & States/UT in India \\
\hline 1 & Rabies & $132 / 132$ & $125 / 125$ & $98 / 98$ & $93 / 93$ & $111 / 111$ & $110 / 110$ & AP, Karnataka, West Bengal \\
\hline 2 & Jap.enceph-alitis(JE) & $1086 / 202$ & $1661 / 293$ & $1730 / 291$ & $1676 / 283$ & $2181 / 254$ & $1674 / 182$ & Assam, UP, WB, Odisha, TN \\
\hline 3 & Malaria & $881730 / 440$ & $1102205 / 562$ & $1169261 / 384$ & $1087285 / 331$ & $844558 / 194$ & $399134 / 85$ & All over India \\
\hline 4 & Chikungunya & 18840/NA & 16049/NA & 27553/NA & 64057/NA & 67769/NA & 57813/NA & MP, M-shtra, G-rat, K-taka \\
\hline 5 & Kala-azar & $13869 / 20$ & $9241 / 11$ & $8500 / 5$ & $6245 / 0$ & $5758 / 0$ & $438 / 0$ & WB, Bihar, Jharkhand \\
\hline 6 & (AES) & $7825 / 1273$ & $10867 / 1719$ & $9854 / 1210$ & $11651 / 1301$ & $13672 / 1097$ & $11382 / 637$ & Assam, Bihar, UP, WB, Odisha, TN \\
\hline 7 & Tetanus & $3410 / 221$ & $3958 / 163$ & 3382/102(p) & $3593 / 158$ & $3281 / 107$ & $9104 / 69$ & Assam, UP, Telangana, M-stra \\
\hline 8 & Dengue & $75808 / 193$ & $40571 / 137$ & $99913 / 220$ & $129166 / 245$ & $188401 / 325$ & $101192 / 172$ & Gujarat, M-rastra, Panjab, Delhi \\
\hline 9 & Diphtheria & $4310 / 67$ & $4455 / 198$ & $3249 / 85(p)$ & $2599 / 176$ & $5421 / 149$ & $11720 / 180$ & Delhi, WB, HP, Rajasthan, Assam \\
\hline 10 & Viral Hepatitis & $110125 / 574$ & $138554 / 400$ & $133625 / 397$ & $145970 / 451$ & $164289 / 537$ & 143974/DNA & UP, Delhi, Punjab, Haryana, AP \\
\hline 11 & Pneumonia & $729891 / 2919$ & $712028 / 2599$ & $642152 / 2410(p)$ & $744865 / 3469$ & $759004 / 3281$ & 928485/NA & Allover India \\
\hline 12 & Meningococcal Meningitis & $3821 / 197$ & $4215 / 158$ & $12002 / 172(p)$ & $3087 / 146$ & 3498/205(p) & $3382 / \mathrm{NA}$ & WB, AP, Bihar, Harayana,UP \\
\hline 13 & Swine Flu(H1N1) & DNA & $937 /$ & $42592 / 2990$ & 1786 & 38811 & $14971 / 1103$ & Gujarat, K-taka, Maharashtra \\
\hline 14 & Cholera & $1130 / 05$ & $844 / 5$ & $889 / 04(p)$ & $718 / 03$ & $508 / 03$ & $651 / 06$ & Ma-stra, Rajasthan, WB, Delhi/AP \\
\hline 15 & Acute Diarrhea & $11413610 / 1629$ & $11748631 / 1337$ & $1233379 / 1216(p)$ & $14166574 / 1555$ & $13416748 / 1362$ & $\begin{array}{l}13194775 \\
/ 1450\end{array}$ & $\begin{array}{l}\text { WB, AP, Bihar, Rajasthan, UP/ } \\
\text { Delhi/ Telangana/ Ka-taka, Odisha }\end{array}$ \\
\hline 16 & Typhoid & $1650145 / 387$ & $1736687 / 425$ & $1845997 / 393$ & $2215805 / 511$ & $2264453 / 496$ & 2308537/399 & All over India \\
\hline 17 & ARDS & $3342310 / 3513$ & $34835743 / 2729$ & $35650431 / 2661$ & $40810524 / 3164$ & $42199633 / 3254$ & $41996260 / 3740$ & Sporadic in whole India \\
\hline 18 & Viral Hepatitis & $110125 / 574$ & $1385584 / 400$ & $133625 / 397(p)$ & $145970 / 451$ & $164289 / 537$ & 143974584 & $\begin{array}{l}\text { AP,MP,Gujarat, Haryana, UP, ,M- } \\
\text { stra,Panjab, UT-hand }\end{array}$ \\
\hline 19 & Meningococci, Meningitis & $3821 / 197$ & $4215 / 128$ & NA & $3087 / 146$ & $3498 / 229$ & $3382 / 152$ & WB, UP, Haryana, Bihar, AP \\
\hline 20 & COVID-19(03/08/2020) & $\begin{array}{l}\text { M- shtra; } 412 \\
28 / 15576\end{array}$ & $\begin{array}{l}\text { Delhi/137677/40 } \\
04\end{array}$ & $\begin{array}{l}\text { Gujarat; } \\
63562 / 2486\end{array}$ & $\begin{array}{l}\mathrm{TN} / 257613 \\
14132\end{array}$ & $\begin{array}{l}\text { K- } \\
\text { taka;134819/249 } \\
6\end{array}$ & $\begin{array}{l}\text { AP: } 158764 / 147 \\
4\end{array}$ & Novice Pandemic 2020; COVID -19 \\
\hline
\end{tabular}


Table 4. The zoonotic diseases mechanism, animals involved and the related fevers

\begin{tabular}{|c|c|c|c|c|}
\hline Type ZD mechanism & Name of ZD & Animals involved & Type of Fever & ZDRIndia(Statewise) \\
\hline $\begin{array}{l}\text { Direct } \\
\text { (Contact, food, Feces, } \\
\text { animal wastes) }\end{array}$ & $\begin{array}{l}\text { Rabies,Avian flu } \\
\text { Anthrax, Salmonellosis } \\
\text { Tinea corpora, Japanese Encephalitis, } \\
\text { wounds, Direct infection, SARS, MERS, } \\
\text { Ebola, }\end{array}$ & $\begin{array}{l}\text { Cat, dog, Cattle monkey, } \\
\text { Chicken Birds, Sheep, rat, } \\
\text { wild animals, bats, Pangolin, } \\
\text { tigers, bovines, }\end{array}$ & $\begin{array}{l}\text { Dog bite, Cat scratch, rabbit fever, Dermatophyte, } \\
\text { rabies, anthrax, brucellosis, leptoSpiros is, } \\
\text { toxoplasmosis, Nausea, Vomiting, Diarrhea, Fever } \\
\text { Chills, Bacillary dysentery Salmonella }\end{array}$ & $\begin{array}{l}\text { AP, Karnataka, WB, } \\
\text { Rajasthan, Odisha } \\
\text { Assam, UP, WB }\end{array}$ \\
\hline $\begin{array}{l}\text { Indirect (Water/air borne) } \\
\text { placenta/amniotic fluids, } \\
\text { urine, milk, feces etc. } \\
\text { Man and nature }\end{array}$ & $\begin{array}{l}\text { Typhoid, Cholera, giardia, Dysentery, E. } \\
\text { coli , Hepatitis-A, Salmonella, Water } \\
\text { brucellosis, Hanta virus, psittacosis } \\
\text { schistosomiasis, leptospirosis }\end{array}$ & $\begin{array}{l}\text { Mosquitoes (Aides, Culet, } \\
\text { Anopheles), People/animals } \\
\text { soil \& Water (Dogs, pigs, } \\
\text { cattle's) }\end{array}$ & $\begin{array}{l}\text { Chikungunya, Dengue, Zika Polio, Malaria, Cholera, } \\
\text { fil -ariasis, Dengue, Scabies, Typhoid, Anemia, } \\
\text { Botulism }\end{array}$ & $\begin{array}{l}\text { M-stra, A\&N Gujarat, } \\
\text { Kerala, AP, Odisha, TN, } \\
\text { Assam }\end{array}$ \\
\hline Vector borne & $\begin{array}{l}\text { Mosquitoes, (different type), Ticks, lice, } \\
\text { fleas, or mites, Hydatid disease, Flies } \\
\text { (Leish maniasis), Rodents (rats flea), } \\
\text { Sand Flea, }\end{array}$ & $\begin{array}{l}\text { Rickettsia; Q-fever, Kala-azar, } \\
\text { chino coccus Larva (Tape } \\
\text { worm), Plague }\end{array}$ & $\begin{array}{l}\text { arbovirus,skin/ mucous membranes infected by } \\
\text { feces/saliva, Parasitic eggs / water \& Food, } \\
\text { slaughter house infect Cats, pigs, cattle, sheep, goat }\end{array}$ & $\begin{array}{l}\text { North India, MP, Bihar, } \\
\text { Jharkhand, WB, East UP } \\
\text { K-taka, TN, Gujarat } 1994\end{array}$ \\
\hline
\end{tabular}

Source: MoHFW, GOI(Zoonotic disease of PH importance),Rao S.S. et al 2012 [45]; 


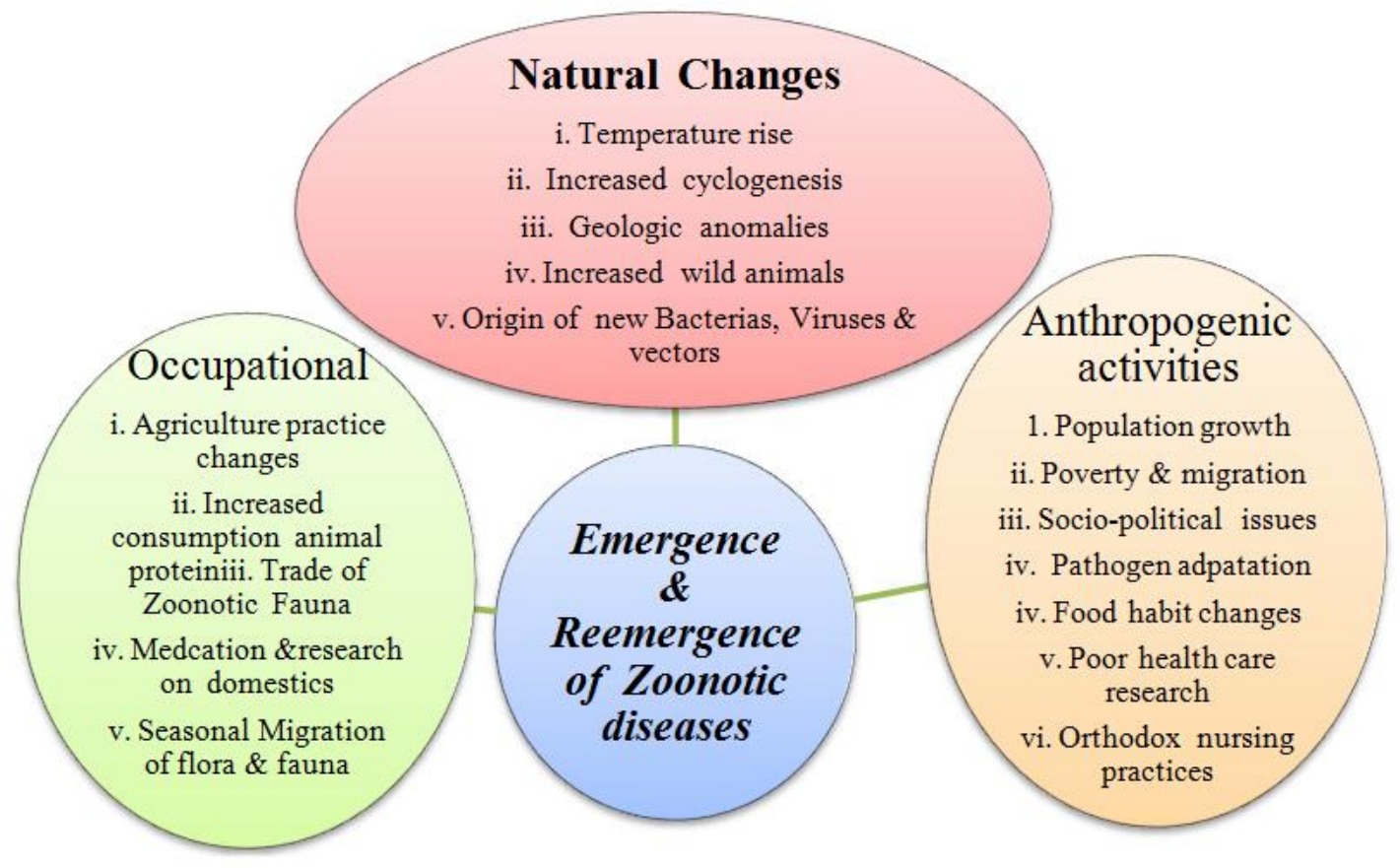

Fig. 6. The emergence and re-emergence of Zoonotic diseases and their associated causes

\subsection{Emergence and Reemergence of Zoonoses}

They are conjoint with de-glaciation, climatic extremes, ecological and permafrost indicators of the tropics, arctic and subarctic areas of the globe. The domesticated animals and arthropod vectors, pathogens and emergence /reemergence with viral mutation have altered the dynamics of human diseases (Fig. 6).

\subsection{Zooneses Transmission Settings}

The different modes for spread of ZD's are (I) Direct Zooneses; direct from infected vertebrate host to human to cause the ZD like rabbis, Anthrax, (ii) Cyclogeneses: multi-vertebrate hosts without invertebrate host for life cycle completion of the ZDs like taeniasis, echinococcosis (iii) Meta-zoonoses; Transmission from man to an invertebrate vector, complete the incubation period and again infect the human get the ZD like Plague, Malaria, Dengue, arbovirus infections, (iv): Sapro-zoonoses; Transmit first to a vertebrate host then to soil/plant and then infect to human the ZD like aspergillosis, crypto-cocosis, zygo-mycosis etc. Simply the Zooneses transmission (ZT) comprises of direct, indirect and vector borne mechanisms Table 4.

\subsection{The Zoonoses and Climate}

The prominent natural causes may be geospatially designed and based on climate change factors like global warming, surface air temperature (SAT), sea surface temperature (SST), Mean sea level rise (MSLR), RMSLR (regional Mean sea level rise), rainfall Pattern and soil condition. Impact may be long term or short term and the zoonoses may be emerging or mutational remerging. The long term expatriations were caused by climatic anomalies and sub-version human health sustainability due to draught, food dearth, hunger, diseases and finally local elimination or migration with social, political and economic unrest. The infectious ZD's is allied with temperature or respiratory problems (Symptomatic) and sometimes without any symptoms and causes short-term suffering and accompanied by death (Asymptotic). Some viral infections are climatic oriented with meteorological anomalies like ENSO (El-Nino Southerly Oscillation), IOD (Indian Ocean Dipole), ONI (Oceanic Niño Index), MJO (Maiden Julien Oscillation), BSISO (Boreal Summer Intraseasonal Oscillation) and ITCZ (Intra-tropical Convergence Zone) that regulate the climate of India and neighboring countries. These ZD's may be local or widespread and short-term or long term. The zoonoses like Leptospirosis (Infectious 
Jaundice) worldwide, occur in tropics with heavy precipitation. However the modern man have learnt how to cope and sustain combating whether it is endemic or pandemic in community or state level, McMichael A. J. [46], Naiker P. R. [47].The anthropogenic zoonoses linked with animal trade, Travel and tourism, Agricultural practices, taming, keeping pets,
Bovine farming, host susceptibility, sex transmitted, societal and political factors, pathogen adaptation and many other factors Naiker P. R. [47], Mishra S P. [35]. The climate change like thawing of glaciers, meteorological extremes, ecological and permafrost manifestations has oriented of the global health Sinha et al. [66].

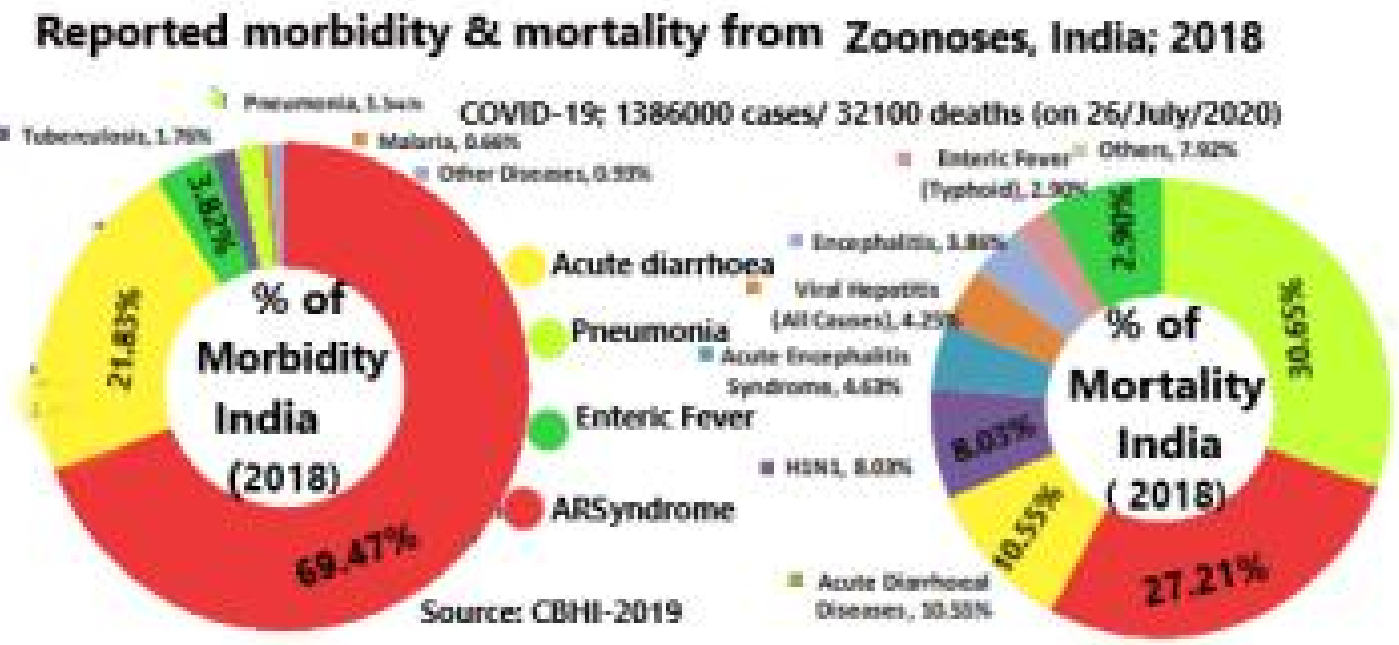

Fig. 7. The reported morbidity and mortality from communicable diseases India; 2018; Source; CBHI; India

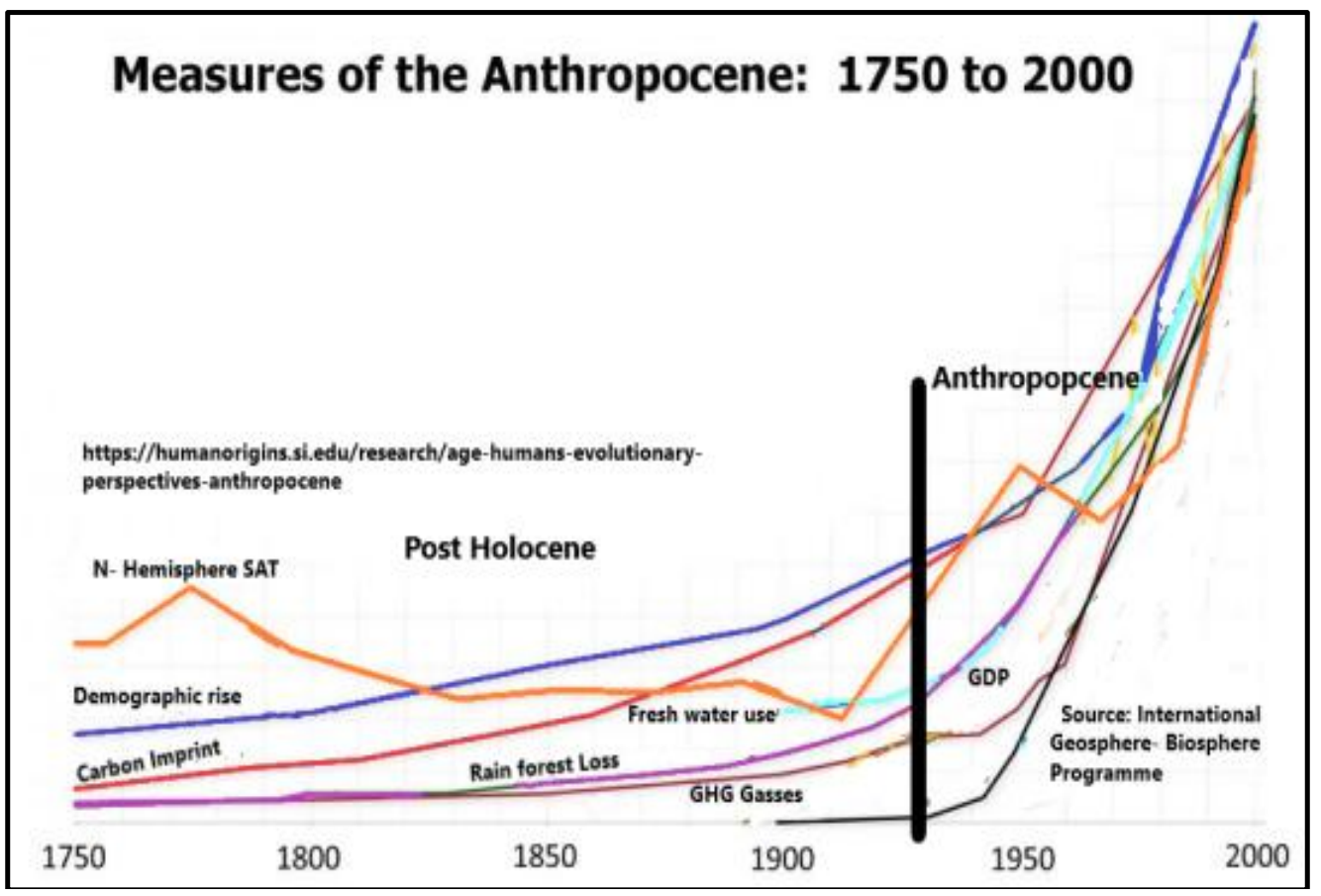

Fig. 8. The natural and anthropogenic parameters from 320 Yrs BP to present of the globe 
Table 5. The $21^{\text {st }}$ century Zoonotic viral diseases with confirmed cases and deaths in India

\begin{tabular}{|c|c|c|c|c|c|c|}
\hline \# & $\begin{array}{l}\text { The zoonotic disease (Start year } \\
\text { in India) } 21^{\text {st }} \text { century }\end{array}$ & Year & Reported cases & No of deaths & $\begin{array}{l}\text { The zoonotic reservoir } \\
\text { (states/places) }\end{array}$ & $\begin{array}{l}\text { Emergent/ re- } \\
\text { emergent }\end{array}$ \\
\hline \multirow[t]{2}{*}{1} & (a)Pneumonic plague (E ) & 2002 & 16 & 4 & Shimla (HP) & Re-emergent \\
\hline & (b) Bubonic plague & 2004 & 08 & 03 & Uttara Khand & Re-emergent \\
\hline 2 & SARS $€$ & 2003 & 19 & Nil & Goa and Pune & Emergent \\
\hline 3 & Meningococcal meningitis & 2005 & 111 & 15 & Old Delhi; UP & Re-emergent \\
\hline 4 & Japanese Encephalitis (E) & 2005 & 6727 & 1682 & UP, North Ind. & Re-emergent \\
\hline 5 & Chikungunya ( $E)$ & 2006 & $1.25 \mathrm{mn}$ & NA & MP, Gujarat. A \&N Isl., Ma-shtra & Re-emergent \\
\hline 6 & H1N1 Flu 2009 (WHO) & 2009 & 27236 & 981 & AP, TN,K-Taka M-shtra, Rajasthan, & Emergent \\
\hline 7 & Nipah (E) & 2018 & 19 & 17 & Kerala & Emergent \\
\hline 8 & COVID-19 (P); 02/08/2020 & 2020 & 1.81million & $38.2 \mathrm{k}$ & All states India & Emergent \\
\hline
\end{tabular}

400; https://www.who.int/csr/don/2005 05 09/en/, Parida M et al., 2006 [49]; https://www . science direct.com/science/article/pii/S1413867012002073;

Mavalankar et al, 2008 [50], Suri et al 2011 [51], Sharma et al., 2015 [52] 
During 2009 more than 50000 cases were reported but cases of mortality were high during 2008. The discrepancy was depending upon meteorological, climatological, geological and anthropogenic factors. Some diseases like Diphtheria, Whooping cough, Measles, Gonococcal Infection, Polio, Syphilis and small pox where cases were reported but the deaths are negligible [48]. Recovery from Zoonoses depends upon the immunity of the affected and claim survival of the fittest. Food insecurity is also causing burden on human health. The yellow fever (infected by mosquitoes) in Africa is claiming 78000 lives/year due to shifting of climate (rainfall and temperature) and geographic changes (Down to earth, 31-7.2020).

\section{$1.1521^{\text {st }}$ Century Emerging Zoonoses}

Emerging infections from different viruses of $21^{\text {st }}$ century are SARS (China), Hanta virus (USA), MERS (Arabian states), Avian flu (H5N1 and H9N in 2013 from china), Bovine Spongiform Encephalitis (BSE), Ebola virus (EVD in 1976 Africa), Nipah virus.(10deaths in Kerala, /2015 and 2018), Swine flu (reemerging 2014-15) and finally in 2019 the virus SARS-CoV2.https://www.india today.in/education-today/gkcurrent-affairs/story/five-dangerous-viruses. The $21^{\text {st }}$ century emerging status of the ZD's with the places of ZDR (Zoonotic disease reservoirs) is given in Table 5.

\subsection{Zoonotic Covid-19}

The CDC (Centre for disease control)and prevention) has little understood the disease and reported that COVID-19 is mostly spreading from Human-Human and there is less confirmation as it is a ZD with less reports from (Cats, Dogs, ferrets, minks and Tigers).Covid-19 link a disease from human to zoonotic by fomite as a high risk respiratory infections and has become fatal pandemic by both the $\alpha, \beta$ (Human) and $Y$ corona (animals and birds) virus ( $\mathrm{Hu} \mathrm{B}$ et al. [53] and [54], Ji et al. [55]; Salata et al. [56]). Launching from China, the pandemic COVID-19, has transmitted and become globally apocalyptic in 213 countries. It is at the cutting edge for the life and livelihood of human species. Lu $\mathrm{H}$ et al [57], Lu R et al. [58], Patel et al. [59] Considering its virulent human surfacing nature, the facts about the disease should not limit within the doctors and researchers. The public should be aware of the ill effects of domestication and its impact of zoonoses on the public health.

\subsection{Societal Impact COVID -19}

According to 2011 Census, about 700 tribal groups $104 \mathrm{mn}$ population reside in the jungles of India being the $2^{\text {nd }}$ largest Demography after Africa. The worst sufferers are the ethnic/aboriginal groups live in NE Himalayan states and eastern Ghats Hills of India in 90 districts (809 blocks) which constitute 75 categories and $45 \%$ population of the ethnic group (ST population) are interdependent with wildlife and jungle flock in terms of food and farming. Once any of the species goes extinction; shall affect other flora and fauna and make the ecosystem genetically and culturally turbulent. There is spread of the diseaseCOVID-19 in the tribal areas in India inclusive Andaman and Nicober Islands. The tribes of18states of India including NE India, EGB hills and WGB hills are vulnerable and also infected Phulbani and undivided Koraput districts of Odisha, Baster districts of Chhattisgarh, tribes of Purlia in WB, Mulugu tribes of Telangana and many other tribes are under the prevalence of the present pandemic. The NE Indians due to their mongoloid features are under racial discrimination and harassment in terms of Chinese link. Their indigenous market stuffs (honey, tamarind, cocoons, kendu leaves and medicinal plants were unsold under the strict regulations of the Government. The home coming of the tribal people of Rajasthan, Gujarat and MP by walking to their native villages by walk or cycle for day's together lack of transport and lockdown has spread the disease enroute and at their own villages without isolation. The after myth of this pandemic is menacing their life as they were more susceptible to hunger looms, infections from the disease COVID-19 but no money with them for treatment Chkma D. et al., [60]. MoTA Annual report [61], Live mint 1st April [62].

\subsection{COVID -19 in India's Prospective}

Initiated at $\mathrm{n}$ in Wuhan city of China; the Severe Acute Respiratory Syndrome (SARS-CoV-2); popularly known COVID-19; had widespread throughout the globe infecting $17.19 \mathrm{mn}$ and causing death toll of $670 \mathrm{k}$ people of various age groups. India stands $3^{\text {rd }}$ position in the world having $1.6 \mathrm{mn}$ confirmed cases with $35 \mathrm{k}$ mortalities against population of 1.38 billion. The trend of the diseases has been noticed as increasing in the confirmed positive cases and decline in the mortality rate. The slum dwellers in urban areas, the reverse migration in the rural 

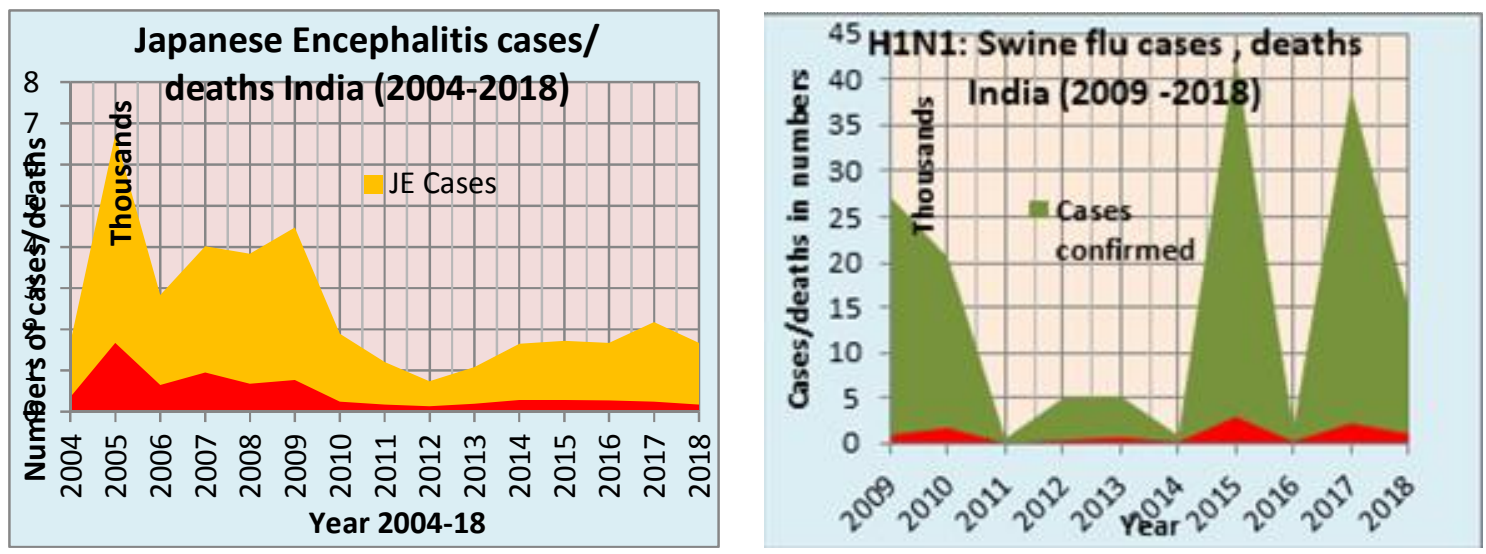

Fig. 9. The cases \& deaths in India for ZD's;

\section{(a) Japanese Encephalitis; (b) Swine flu H1N1}
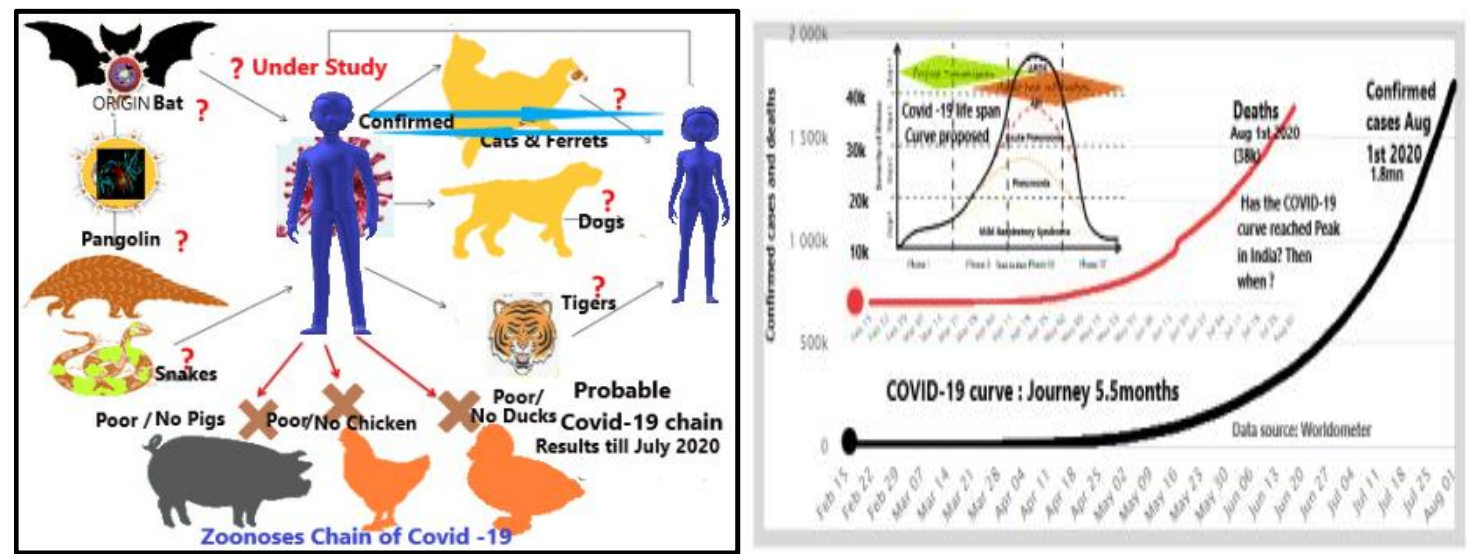

Fig. 10(a). The sources of Corona SARS -2 virus linked with zoonotic species (sources; Tiwari et al 2020), Fig 10(b). Status of impact of the diseaseCOVID-19 reaching the peak in India (Data source: Worldometer [65])

districts are the most affected areas in India. The pandemic has shattered the economic stand point of these areas due to closure of industries, loss of jobs and shall put these groups under the unique cataclysm. The end shall be most of the rich will cure and paupers left to die from ignorance of social distanceshttps://www.iwgia.org/en/india/3550covid-19-india-reverse-migration.html. The world has observed the zoonosis day globally on 6th July, 2020 under One Health.

\subsection{Model One Health}

The intra-relation between conjoint health problems of human, animal under the vagaries of nature and their inter diffusion is the prima-facie of one health model at the wake of surged emerging/reemerging ZD's. As cataclysmic disasters the human health is at stake which should be viewed with a holistic approach. About $>70 \%$ of infectious diseases come from domesticated/ wild animals to man. The pandemic sources of diseases like influenza (H1N1), SARS in various metamorphosed formulae, EBOLA and HIV (AIDS) are the devastators. Carol Rubin, [40]. NHP 2019 has mentioned that the communicable, neonatal, maternal, and nutritional ailments, measured by disability-adjusted life years (DALYs). They are the total of years missing due to ill-health, disability or untimely death. The DALY has fallen from $61 \%$ to $33 \%$ during 1990 to 2016 . However rise in DALY's report indicate during last two to three decades chronic non-communicable (NCD) diseases like cardiovascular disease (CVD), diabetes, chronic obstructive pulmonary disease (COPD), cancers, mental health disorders and injuries. The NCD's have increased from $30 \%$ to 55\% between 1990 and 2016. The Zoonotic 
diseases have urged the health care units should not be delimited within specialists and virologists without vaccine to attend morbid patients with various chronic diseases but should be open to all for ameliorative measures Kelly et al. [63].

\section{DISCUSSION}

National Health profile 2019 as reported by CBHI has predicted the life expectancy in India has been surged to 68.7 years (2012-16) against 49.7 years during $1970-75$. The men to women life expectancy ratio has been raised to 70.2 and 67 years where as the infant mortality is high (33 child /1000 births). The \% of population below poverty line in 2011 census is $21.9 \%$ consisting of $269.78 \mathrm{mn}$ (National health profile 2019; CBHI [63]). The most susceptible poor and migrant people are infected from ZD's like SARS, HIV, MERS, Ebola, and Cholera, Bubonic plague resulting from lack of proper sanitation and health care and living among domesticated animals.

Wildlife markets like animal gathering, trading within crowd, wild animals and birds within the Zoo's (Hat's, Mela'setc.) are the hotspot zone for pathogen transfer without a planned vending zone. It is main source of transfer of ZD's. So present demand is to plan such vending zones, conceal/bridge gaps between researches and health workers from domestication from infection by maintaining a diaphragm at the human animal interface. There is also need for segregation of aboriginal species and the IAS to reduce genome transfer, Thomas P. K. [6], Darwin C. R. [7], Andresiuk V. et al. [19], Carlo Rubin et al. [41], CGHI DGHS- 2019 [64] and Worldo-meter COVID-19 [65].

Iteration of ZD's in India due to emergence and its re-emergence is common to people of India. Since the diaphragm between the human and its domestic surrounding has ruptured, the outbreak in the form of endemic and pandemic of bacterial, vector carried and virus transmitted has threatened the domestic and the human species. Prioritization of ZD's and identification of ZDR is the urge of $21^{\text {st }}$ century, in the context of SARS, MERS, Zika, Rabies, Avian Influenza (H5N1), Influenza A (H1N1) with special reference to the present highly mutating apocalyptic Pandemic the SARS-CoV-2 (COVID-19). The local level search of its origin, its prognosis and corresponding Vaccine under the same umbrella of One Health strategies is urged for defeating the $6^{\text {th }}$ extinction through SARS-CoVID-2 (COVID-19) pandemic.

The most catalytic anthropogenic activities like, deforestation, hunting, poaching, improper waste disposals, industrialization, mining activities with rampant travel, and animal trade are inviting Zoonoses. Cholera in fag end of 19th century, H1N1 flu during 1920's had highlighted the human surfacing in past but we have less learnt about those ferocities. The COVID-19 pandemics have attacked our life and lively hood both which has put us in doubt about our anthropogenic supremacy over the animals.

\subsection{Regulating Human Animal Interface}

There is no diaphragm at the human- animal interfaces which is augmenting the spread of $Z D$ and there is no pathogen screening unit nationally or internationally. Along with India, the developing countries have mass of people under smart living with desperate economy. The slum dwellers and the migrant community in large cities leave in slums and below health care standards. The present society is lack of pathogen screening, animal trade regulations, animal's movement, and hunting and poaching laws.

\subsection{Immunity and Health Status in Anthropocene}

The Holocene hominids were strong enough to adapt them to the harsh, frigid and climate changes to sustain themselves with extreme conditions. During Mesolithic era; hunting, food gathering and fishing were the main practice with hard physical labour and was providing more immunity to health and were mostly depending directly on nature.. But the processed and the adulterated food consumed by the modern people make them inept to endure the bacterial, viral and microbial attacks for lack of immunity and adaptability. The exponential human growth, improper food pattern, life style, odd habits have kept them in poor health.

\subsection{Protecting Zoonoses from Domestica- tion}

There should be regionalized screening machinery to watch and record and report prior zoonotic outbreaks. H1N1 had compelled the British to invoke the Epidemic Diseases Act, 1897; which was not enough to keep us away from the officially declared pandemics the 
COVID-19. The Maharashtra state has been compelled to design and impose stringent laws like COVID-19 Regulations, 2020. However it is ubiquitous to frame laws to abate contact between zoonotic animals and humans like banning wildlife trade and markets. It is also necessary to frame a regionalized Zoonotic disease surveillance system with testing, screening, monitoring to ameliorate Zoonoses prior to developing an endemic even.

\subsection{Prevention of Zoonoses}

The preventive actions to avoid zoonoses are cleaning the feces of domestics and pets regularly using safety gadgets and PPE kits and the zoonotic worker should frequently cleanse his exposed body and sterilize after handling the animal. Do not kiss or licked by the pet and allow your child to play with. Do not feed raw meat, share their eating utensils and keep their food outdoor not to attract other zoonotic animals. The clip dog's and cat claws regularly and does not allow your pets to be inter-mix with neighbors or jungle folks. Any animal found infected they must be kept segregated to avoid contamination. The amelioration of ZD's are early diagnosis, effective control, isolation both animals from society and maintenance of social distancing among the people, lock downs, quarantines, and prompt treatment, vaccinating early, diagnosis and prompt treatment, disposing the animal under risk and finally a high level awareness, periodically testing of pets, vector control and immunizations to all, and stringent regulation. However, present pandemic COVID19 has forced us for our sustenance of life and livelihood for want of vaccine. Under the present crisis, it is essential to practice five ' $T$ ' $s$ ' (maximizing testing, tracing, treatment to all confirmed cases, train public and trade to continue uninterrupted) so that life and livelihood both shall be normal.

\section{CONCLUSION}

Huge numbers of potholes that lie in the cut edge for the proliferation zoonotic diseases in India. The impact of slum dwelling, animal farming, unhealthy work culture, food pattern, migration, poverty, insanitary health care, climate change and mutation of pathogens may be contributing India and many developing countries towards emergence of pockets of ZDR. Public health care surveillance, changed pattern in nursing care, proper vaccines, periodic surveillance, authentic data recording and analysis with identification of vulnerable pockets of ZDR are essential. Creating awareness and implementing preventive measures like social distancing, lock down, lock outs and quarantining of the affected is the need of the hour in India.

\section{DECLARATION}

Any medical evaluation or statistical information is for a common man/ health care personnel and not an instrument for use by a medical professional. Kindly consult your doctor if there is any query about any zoonoses.

\section{COMPETING INTERESTS}

Authors have declared that no competing interests exist.

\section{REFERENCES}

1. Swain S, Ku S, GSP, Singh BS, Aggarwal D. Zoonotic diseases in India. Indian Journal of Community Medicine: Official Publication of Indian Association of Preventive \& Social Medicine. 2020;45(1): S1-S2.

2. Available:https://doi.org/10.4103/ijcm.IJCM $360 \_19$

3. Dubal ZB, Barbuddhe SB, Singh NP. Important zoonotic diseases: Prevention and control. Technical Bulletin No. 39. ICAR Research Complex for Goa (ICAR), Old Goa 403 402, Goa, India.

4. CBHI, DGHS, Ministry of Health and Family Welfare. Government of India. National Health Profile: 2018. CBHI, DGHS, Ministry of Health and Family Welfare. Government of India; 2018.

5. Nath B. The role of the animals in early prehistoric culture of India. Ind Museum Bulletin. 1969;4(2):102-110.

6. Thomas PK. Zoological evidences from pre-historic India; with special reference to domestication, Bul. of the Deccan College Post-Graduate and Research Inst. 1974;1(4):195-210.

7. Darwin CR. The variation of animals and plants under domestication. London: John Murray. 1868;1(2):411- 486.

8. Clutton-Brock J. A natural history of domesticated mammals. Cambridge Univ. Press. 1987;208.

9. Francis RC. Domesticated evolution in a man-made evolution. New-York: WW Norton \& Company. 2015;484. 
10. Alves RRN, Albuquerque UP. Ethnozoology: Animals in our lives. London: Academic Press; 2018;540.

11. Teletchea F. Animal domestication: A brief overview; Fabrice Teletchea; Teletchea, Intech Open; 2019.

DOI: 10.5772/intechopen.86783

Available:https://wwwintechopen.com/book s/animal-domestication/animal-

domestication-a-brief-overview

12. Ahmad HI, Ahmad MJ, Jabbir F, Ahmar S, Ahmad N, Elokil AA, Chen J. The domestication makeup: Evolution, survival, and challenges. Ecol. Evol; 2020.

Available:https://doi.org/10.3389/fevo.2020 .00103

https://www.frontiersin.org/articles/10.3389 /fevo.2020.00103/full

13. Mishra Siba Prasad. Human evolution/extermination up to present anthropocene: India. Journal of Shanghai Jiaotong University; JSJ.U-2222.14-F (1).pdf. 2020;16(7):115-133.

14. Sehgal S, Bhatia R. Zoonoses in India. Journal Communication Diseases. 1990;22(4):227-235.

15. Dhiman RC, Tiwari A. Emergence of zoonotic diseases in India: A systematic review. Med Rep Case Stud. 2018;3: 163.

DOI: $10.4172 / 2572-5130.1000163$

16. Chinchwadkar P, Panda P. An assessment of knowledge regarding the risk of zoonoses and hygiene practices among females with livestock in South-West Delhi, India: A cross-sectional study. Indian J Community Med. 2020;45:S1:38-42.

17. Bhatia BB. Current status of food-borne parasitic zoonosis in India. Southeast Asian J Trop Med Public Health. 1991;22: 36-41.

18. Traub RJ, Robertson ID, Irwin PJ, Mencke $\mathrm{N}$, Thompson RC. Canine gastrointestinal parasitic zoonoses in India. Trends Parasitol. 2005;21(1):42-48. DOI: 10.1016/j.pt.2004.10.011.

19. Andresiuk V, Sardella N, Denegri G. Seasonal fluctuations in prevalence of dog intestinal parasites in public squares of Mar del Plata city, Argentina and its risk for humans. Rev Argent Microbiol. 2007;39(4): 221-224.

20. Deplazes $P$, van Knapen F, Schweiger A, Overgaauw PA. Role of pet dogs and cats in the transmission of helminthic zoonoses in Europe, with a focus on echinococcosis and toxocarosis. Vet Parasitol. 2011;182(1):41-53.

DOI: 10.1016/j.vetpar.2011.07.014

21. Singh BB, Gajadhar AA. Role of India's wildlife in the emergence and reemergence of zoonotic pathogens, risk factors and public health implications. Acta Trop. 2014;138:67-77.

DOI: 10.1016/j.actatropica.2014.06.009

22. Crutzen PJ, Stoermer EF. The anthropocene. Global Change News. 2020;41:17-18.

23. Zalasiewicz J, Williams $M$, Steffen $W$, Crutzen P. The new world of the Anthropocene. Environ. Sci. Technol. 2010;44:2228-2231.

DOI: $10.1021 /$ es903118j

24. Mishra SP. The apocalyptic anthropocene epoch and its management in India. Int. Jour. Adv. Research. 2017;5(3):645-663.

DOI: $10.21474 /$ JJAR01/3555

25. Lewis SL, Maslin MA. Defining the anthropocene. Nature. 2015;519:171-180.

26. LeCain Timothy James. Against the anthropocene; A neo-materialist perspective. International Journal for History, Culture and Modernity; HCM. 2015;3(1).

DOI: $10.18352 / \mathrm{hcm} .474$

27. Ellis E, Maslin M, Boivin N. Involve social scientists in defining the Anthropocene. Nature. 2016;540:192-193.

28. Zeder MA. Domestication and early agriculture in the Mediterranean Basin: Origins, diffusion and impact. Proceedings of the National Academy of Sciences. 2008;105(33):11597-11604.

29. Zeder MA. Pathways to animal domestication. In: Gepts P, Famula TR, Bettinger RL, et al. Editors. Biodiversity in Agriculture: Domestication, Evolution, and Sustainability. Cambridge: Cambridge University Press; 2012.

30. Larson G, Fuller DQ. The evolution of animal domestication. Annual Review of Ecology, Evolution, and Systematics. 2014;66:115-136.

31. Scherf BD, Pilling D. The Second Report on the state of the world's animal genetic resources for food and agriculture. Rome: FAO; 2015.

32. Leroy $G$, Baumung $R$, Boettcher $P$, Besbes $B$, From T, Hoffmann I. Animal genetic resources diversity and ecosystem services. Glob. Food Securi. 2018;17:8491. 
33. Teletchea F. Wildlife conservation: Is domestication a solution? In: Lameed GA; 2017.

Available:https://www.intechopen.com/boo ks/global-exposition-of-wildlife-

management/

DOI: $10.5772 / 65660$

34. Teletchea F. Animal domestication: A brief overview; In: Lameed GA; 2019.

Available:https://www.intechopen.com/boo ks/animal-domestication/animaldomestication

DOI: $10.5772 / 65660$

35. Mishra SP. Human evolution/extermination up to present anthropocene: India. Journal of Shanghai Jiaotong University; JSJ.U2222.14-F (1).pdf. 2020;16(7):115-133.

36. Joshi RV. Late Mesolithic culture in central India, F. Bordes\& D. de SonnvilleBordes, (Eds.), La Prehistorise: Problems et Teudences Paris, France. 1968;245-254.

37. Alur KR, GR, Mishra VD, Mandal D, Mishra $\mathrm{BB}$, Pal JN. Faunal remains from the Vindhyas and the Ganga valley. Sharma Beginnings of Agriculture. 1980;201-27.

38. Gupta Anil K. Origin of agriculture and domestication of plants and animals linked to early Holocene: Climate amelioration; review article; Current Science. 2004;87(1):54-59.

39. McHugo Gillian $\mathrm{P}$, Dover Michael J, Machugh David E. Unlocking the origins and biology of domestic animals using ancient DNA and paleogenomics. BMC Biology. 2019;17(1):98.

DOI: $10.1186 / \mathrm{s} 12915-019-0724-7$

PMC: 6889691

PMID: 31791340

40. Day MJ, Breitschwerdt E, Cleaveland S, Karkare U, Khanna C, Kirpensteijn J, Kuiken $\mathrm{T}$, et al. A surveillance of zoonotic infectious disease transmitted by small companion animals. Emerg Infect Dis. 2012;18(12):1.

DOI: 10.3201/eid1812.120664

PMCID: PMC3557867

41. Carol Rubin, Cleaveland S, Karkare U, Khanna Chand, Thiermann A. People Can catch diseases from their pets; Based on the article Surveillance of Zoonotic Infectious Disease Transmitted by Small Companion Animals Day MJ, Reitschwerdt E; 2012,

42. Rist CL, Arriola CS, Rubin C. Prioritizing zoonoses: A proposed one health tool for collaborative decision-making. PLoS ONE. 2014;9(10).
Available:https://doi.org/10.1371/journal.po ne.0109986

43. Mishra Siba Prasad, Mishra Durga Prasad. Anthropocene-Bio-geography need reverse gearing in India: Beyond domestication and farming. International Journal of Current Engineering and Technology. 2018;8(6):1500-1518, DOI: https://doi.org/10.14741/ijcet/v.8.6.1

44. IUCN (International Union for Conservation of Nature). The IUCN Red List of Threatened Species. Version. 2020;1. Available:http://www.iucnredlist.org

45. Rao SS, Mehra B, Narang R. The spectrum of hydatid disease in rural central India: An 11-year experience. Ann Trop Med Public Health. 2012;5:225-30.

46. McMichael AJ. Insights from past millennia into climatic impacts on human health and survival. PNAS. 2011;109(13):47304737.

Available:https://doi.org/10.1073/pnas.112 0177109

47. Naicker Preneshni R. The impact of climate change and other factors on zoonotic diseases. Archives of Clinical Microbiology, Pubmed. 2011;2(2):4.

DOI: $10: 3823 / 226$

48. Gupta ML, Sharma A. Pneumonic plague, Northern India, 2002. Emerg Infect Dis. 2007;13(4):664-666.

DOI: 10.3201/eid1304.051105

49. Parida M, Dash PK, Tripathi NK, Ambuj Sannarangaiah S, Saxena $P$, Agarwal S, Sahni AK, Singh SP, Rathi AK, Bhargava R, Abhyankar A, Verma SK, Rao PV, Sekhar K. Japanese Encephalitis Outbreak, India, 2005. Emerging infectious diseases. 2006;12(9):1427-1430.

Available:https://doi.org/10.3201/eid1209.0 60200

50. Mavalankar D, Shastri P, Bandyopadhyay $\mathrm{T}$, Parmar J, Ramani KV. Increased mortality rate associated with chikungunya epidemic, Ahmedabad, India. Emerg Infect Dis. 2008;14(3):412-415.

DOI: $10.3201 /$ eid1403.070720

51. Suri JC, Sen MK. Pandemic influenza Indian experience. Lung India: Official organ of Indian Chest Society. 2011;28(1):2-4.

Available:https://doi.org/10.4103/09702113.76292

52. Sharma RB, Husain M. Reemergence of Swine Flu H1N1 in India: First outbreak; Review Article; Austin J Infect Dis. 2015;2(1):1015. 
53. Hu B, Ge X, Wang LF, Shi Z. Bat origin of human coronaviruses. Virol J. 2015;12: 221.

54. Hu B, Zeng LP, Yang $X L$, Ge $X Y$, Zhang W, Li B, Xie JZ, Shen XR, Zhang YZ, Wang N, Luo DS, et al. Discovery of a rich gene pool of bat SARS-related coronaviruses provides new insights into the origin of SARS coronavirus. PLoS Pathog. 2017;13(11):e1006698.

55. Ji W, Wang W, Zhao X, Zai J, Li X. Crossspecies transmission of the newly identified coronavirus 2019-n; CoV. J Med Virol. 2020;92(4):433-440.

56. Salata C, Calistri A, Parolin C, Palù G. Coronaviruses: A paradigm of new emerging zoonotic diseases. Pathogens and Disease. 2020;77(9):006.

Available:https://doi.org/10.1093/femspd/ft aa006

57. Lu H, Stratton CW, Tang YW. Outbreak of pneumonia of unknown etiology in Wuhan China: The mystery and the miracle. J Med Virol. 2020;92(4):401-402.

58. Lu R, Zhao X, Li J, Niu P, Yang B, Wu H, Wang W, Song $\mathrm{H}$, Huang B, Zhu N, et al. Genomic characterisation and epidemiology of 2019 novel coronavirus: Implications for virus origins and receptor binding. Lancet. 2020;395(10224):565574.

59. Patel A, Jernigan DB, 2019-nCoV CDC Response Team. Initial Public Health Response and Interim Clinical Guidance for the 2019 Novel Coronavirus Outbreak United States. MMWR Morb Mortal Wkly Rep. 2020;69(5):140-146.

60. Chkma D, Chakma P. COVID-19 in India: Reverse migration could destroy indigenous communities; IWIGA; 2020.

Available:https://www.iwgia.org/en/india/35 50-covid-19-india-reverse-migration.html

61. Ministry of Tribal Affairs, Annual Report; 2018-19.

Available:https://tribal.nic.in/writereaddata /Annual Report/AREnglish1819.pdf

62. Coronavirus outbreak: Andaman's indigenous tribes face extinction threat, livemint; 2020.

Available:https://www.livemint.com/news/in dia/coronavirus-outbreak-andaman-sindigenous-tribes-face-extinction-threat11585681835563.html

63. Kelly TR, Machalaba C, Karesh WB, Crook PZ, Gilardi K, Nziza J, et al. Implementing one health approaches to confront emerging and re-emerging zoonotic disease threats: Lessons from predict, one health outlook. 2020;2(1):1-7.

Available:https://doi.org/10.1186/s42522019-0007-9

64. CBHI, DGHS, Ministry of Health and Family Welfare. Government of India. National Health Profile: CBHI, DGHS, Ministry of Health and Family Welfare. Government of India; 2019.

65. Worldometer for COVID-19.

Available:https://www.worldometers.info/co ronavirus/ on date 01.08 .2020

66. Sinha A, Cannariato KG, Stott LD, Cheng $\mathrm{H}$, Edwards RL, Yadava MG, Ramesh R, Singh IB. A 900-year (600 to 1500 A.D.) record of the Indian summer monsoon precipitation from the core monsoon zone of India. Geophys. Res. Lett. 2007;34: L16707. DOI: $10.1029 / 2007 G L 030431$

(c) 2020 Mishra and Mishra; This is an Open Access article distributed under the terms of the Creative Commons Attribution License (http://creativecommons.org/licenses/by/4.0), which permits unrestricted use, distribution, and reproduction in any medium, provided the original work is properly cited.

Peer-review history:

The peer review history for this paper can be accessed here: http://www.sdiarticle4.com/review-history/60644 